Discussion Paper No. 13-015

The Effect of

Patent Litigation on Firm Performance Evidence for Germany

Paula Schliessler

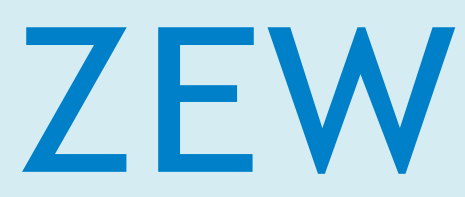

Zentrum für Europäische Wirtschaftsforschung GmbH Centre for European Economic Research 
Discussion Paper No. 13-015

\title{
The Effect of \\ Patent Litigation on Firm Performance - Evidence for Germany
}

\author{
Paula Schliessler
}

Download this ZEW Discussion Paper from our ftp server:

http://ftp.zew.de/pub/zew-docs/dp/dp13015.pdf

Die Discussion Papers dienen einer möglichst schnellen Verbreitung von neueren Forschungsarbeiten des ZEW. Die Beiträge liegen in alleiniger Verantwortung der Autoren und stellen nicht notwendigerweise die Meinung des ZEW dar.

Discussion Papers are intended to make results of ZEW research promptly available to other economists in order to encourage discussion and suggestions for revisions. The authors are solely responsible for the contents which do not necessarily represent the opinion of the ZEW. 


\section{Non-technical Summary}

While the benefits of patents for society as well as for patentees have extensively been studied in the theoretical and empirical economics of innovation literature, researchers in recent years have more and more concentrated on potential negative effects of patents. These negative effects can arise if the estimated costs of the patent system to an innovator exceed the estimated benefits (Bessen and Meurer 2008). This can for example be the case if the costs of defending a patent right exceed the profits of owning it. If there is a negative impact of patent litigation for patentees or inadvertent infringers an ex-post tax is imposed on the innovative effort which results in an ex-ante reduction of innovation incentives (Bessen Meurer 2008).

Against this background the contribution at hand considers the costs and benefits of patents by analyzing how patent litigation affects the firm value of the disputing firms.

Making use of the fact that patents involved in patent infringement litigation constitute highly valuable intangible assets I expect decisions about the infringement of these highly valuable patents to be reflected in the value of the firms involved in litigation.

This paper has two main objectives. The first objective is to model, in a stylized way, the impact of patent litigation and its outcome on the firm value of the plaintiff and the defendant, taking into account the particularities of the German patent litigation system. The second objective is to empirically test the hypotheses derived from this stylized model by using changes in credit rating for German firms as a proxy for changes in firm value.

I find evidence that patent litigation is indeed reflected by changes in the firm value of plaintiffs and defendants. Defendants are negatively affected by a loss in trial or a settlement deal, while a victory leaves their firm value unchanged. I further show that small and inexperienced defendants are at a disadvantage compared to larger and more experienced firms, indicating that they are affected more severely by business disruption and financial distress. By contrast I find a positive treatment effect of litigation on the plaintiffs, independent of the outcome of the case. The results match theoretical considerations on the functioning of the bifurcated patent litigation system in Germany: The temporal separation of decisions on patent infringement claims and corresponding patent invalidity (counter) claims provides a strategic advantage to the plaintiff. The delayed decision of invalidity counterclaims (temporarily) shifts a

large share of the bargaining power to the plaintiffs as they have little to lose from the infringement trial. This may lead to defendants being forced into unfavorable settlement agreements. 


\section{Das Wichtigste in Kürze}

Während der private und gesellschaftliche Nutzen von Patenten in der theoretischen und empirischen Innovationsökonomik bereits ausgiebig erforscht wurde, mehren sich in den letzten Jahren zunehmend Studien, die potentielle negative Effekte von Patenten aufgreifen. Diese entstehen, wenn die für einen Innovator durch das Patentsystem entstehenden Kosten den Nutzen übersteigen (Bessen und Meurer 2008). Wenn zum Beispiel Patentstreitigkeiten einen rechtmäßigen Patentinhaber oder einen versehentlichen Verletzer eines Patentes schädigen, gleicht dies einer ex-post Steuer auf den Innovationsaufwand und führt zu einer ex-ante Reduktion von Innovationsanreizen (Bessen und Meurer 2008).

Vor diesem Hintergrund untersucht diese Studie wie Patentverletzungsverfahren den Firmenwert des Klägers (Patentinhabers) und des Beklagten beeinflussen. Aufgrund der Tatsache, dass in Patentprozesse involvierte Patente besonders wertvoll sind, erwarte ich, dass sich Entscheidungen über die Verletzung dieser Patente im Firmenwert widerspiegeln.

Diese Studie hat zwei Ziele. Zum einen wird der Einfluss von Patentverletzungsprozessen und deren Ausgang auf Kläger und Beklagten in einem stilisierten Modell dargestellt. Hier wird insbesondere auf die Eigenheiten des deutschen Rechtssystems eingegangen. In einem zweiten Schritt werden die aus dem Modell abgeleiteten Hypothesen empirisch getestet, indem Veränderung im Bonitätsindex einer Firma als Indikator für Veränderungen im Firmenwert genutzt werden.

Die Ergebnisse zeigen, dass sich Patentverletzungsprozesse tatsächlich im Firmenwert widerspiegeln. Für die Beklagten ist der Einfluss negativ, wenn sie verlieren oder einem Vergleich zustimmen, während sich bei einem Sieg keine Veränderung zeigt. Des Weiteren wird deutlich, dass kleine und unerfahrene Beklagte im Vergleich zu großen und erfahreneren Firmen im Nachteil sind, sobald sie in einen Prozess involviert werden. Dies deutet darauf hin, dass sie stärker von durch Unsicherheit ausgelösten wirtschaftlichen und finanziellen Schwierigkeiten betroffen sind.

Im Gegensatz dazu zeigt sich ein durchgängig positiver Effekt von Verletzungsverfahren auf den Kläger (Patentinhaber), unabhängig vom Prozessausgang.

Die Ergebnisse stimmen mit den theoretischen Überlegungen zur Praxis des deutschen Patentverletzungssystems überein. Die zeitliche und örtliche Trennung von Patentverletzungsklagen und den zugehörigen, als Verteidigung der Beklagten genutzten, Patentnichtigkeitsklagen, bringt dem Patentinhaber einen strategischen Vorteil. Da Nichtigkeitsklagen meist erst nach dem Urteil zur Patentverletzung entschieden werden, liegt ein Großteil der Verhandlungsmacht beim Kläger, der nur indirekt vom Verlust seines Patents bedroht ist. Dies erhöht seinen Verhandlungsspielraum im Patentverletzungsprozess und ermöglicht einen vorteilhaften Vergleich. 


\title{
The Effect of Patent Litigation on Firm Performance - Evidence for Germany ${ }^{\star}$
}

\author{
Paula Schliessler ${ }^{\mathrm{a}}$ \\ January 2013 \\ ${ }^{a}$ Centre for European Economic Research (ZEW) \& KU Leuven \\ schliessler@zew.de
}

\begin{abstract}
I analyse how patent litigation outcome in Germany affects the performance of the disputing firms by interpreting changes in a firm's credit rating as a proxy for changes in firm performance. The results match theoretical considerations on the functioning of the bifurcated German patent litigation system: The separation of litigation and invalidity decisions, resulting in invalidity decisions taking much longer than decisions on infringement, provides patent holders with a window of opportunity to enforce patents that may later be invalidated. This shifts a major share of the immediate risk to the defendant and allocates bargaining power to the plaintiff. The estimation results provide support for this incongruity. Plaintiffs on average profit from litigation while defendants agreeing upon a settlement deal lose as much as defendants losing in trial. I further show that small, inexperienced defendant firms are at a disadvantage when dealing with litigation.
\end{abstract}

Key words: Patent, Patent Litigation, Credit Rating, Firm Value JEL: O34, K41

\footnotetext{
ऋ I am grateful for the funding of this research project by the Centre for European Economic Research (ZEW) within the Research program "Strengthening Efficiency and Competitiveness in the European Knowledge Economies" (SEEK) and by the Thyssen Foundation. I thank Dirk Czarnitzki, Antonio Della Malva, Reinhilde Veugelers, Daniel Höwer, Katrin Cremers, Bart Leten, Jörg Claussen, Bettina Peters for helpful comments.
} 


\section{Introduction}

The benefits of patents for society as well as for patentees have extensively been studied in the theoretical and empirical economics of innovation literature (Nordhaus 1962, Jaffe and Traitenberg 2002, Scotchmer 2004). Private benefits arise from innovation returns to the patented technology that exceed the patent's R\&D costs. These materialize through an increased market share, a price premium for high quality products, the reduction of production costs or from licensing revenues (Greenhalgh and Rogers 2007). Many contributions have shown that patents and patent quality as measured by forward citations in general have a positive effect on firm value that goes beyond the R\&D expenditures of the firm (Hall 2000, Hall, Jaffe and Trajtenberg 2005, Czarnitzki and Kraft 2004).

In recent years however, with the increased focus on the notion of probabilistic patents (Lemley and Shapiro 2005), researchers have more and more stressed potential negative effects of patents. These negative effects can arise if the estimated costs of the patent system to an innovator exceed the estimated benefits (Bessen and Meurer 2008a). This is the case if the profit an innovating firm receives from owning its own patents is smaller than the cost it has to incur to hold off allegations of patent infringement (Collins 2009, p.1). These costs may for example be related to the validity decision of the patent. Farrell and Shapiro (2008) demonstrate that in case of uncertain property rights determining patent validity prior to licensing (as a measure to avoid litigation) is socially beneficial as weak patents can still yield high licensing royalties because "challenging the patent is a public good for the downstream firms" (Farrell and Shapiro 2008, p. 1362). And Shapiro (2010) shows that for weak patents, covering a minor feature of a high-margin product that takes time to redesign, a large fraction of royalties negotiated during patent litigation can be attributable to hold-up and not to the value of the patented technology as such.

If there is a negative impact of patent litigation for patentees or inadvertent infringers an ex-post tax is imposed on the innovation (Bessen and Meurer 2008 b, p. 3) which can result in an ex-ante reduction of innovation incentives (Bessen and Meurer 2008b, p.26).

Against this background the contribution at hand considers the costs and ben- 
efits of patents by analysing how patent litigation affects the performance of the disputing firms. Making use of the fact that patents involved in patent infringement litigation are generally located the very top of the patent value distribution (Lanjouw Schankermann 2001, 2004, Cremers 2004) and thus constitute highly valuable intangible assets I expect decisions about the infringement of these highly valuable patents to be reflected in the performance of the firms involved in litigation.

This paper has two main objectives. The first objective is to model, in a stylized way, the impact of patent litigation and its outcome on the firm value of the plaintiff and the defendant, taking into account the particularities of the German patent litigation system. The second objective is to empirically test the hypotheses derived from this stylized model by using changes in credit rating for German firms as a proxy for changes in firm performance. A conditional difference-in-difference approach can be applied to evaluate the effect of patent litigation on the performance of both plaintiff and defendant, which is then analyzed with respect to differences between trial outcome, trial-specific characteristics as well as firm characteristics.

I find evidence that defendants are negatively affected by a loss in trial or a settlement deal, while a victory leaves their rating unchanged. I further show that small and inexperienced defendants are at a disadvantage compared to larger and more experienced firms, indicating that they are affected more severely by business disruption and financial distress. By contrast I find a positive treatment effect of litigation on the plaintiffs, independent of the outcome of the case. The results match theoretical considerations on the functioning of the bifurcated patent litigation system in Germany: The temporal separation of decisions on patent infringement claims and corresponding patent invalidity (counter) claims provides a strategic advantage to the plaintiff. The delayed decision of invalidity counterclaims (temporarily) shifts a large share of the bargaining power to the plaintiffs as they have little to lose from the infringement trial. This may lead to defendants being forced into unfavorable settlement agreements.

This paper builds on the existing literature on the impact of litigation on firm value, but to my knowledge is the first to disentagle the effect with respect to the different trial outcomes and the first to consider the particularities of the German system.

The remainder of this paper is organized as follows: Section 2 summarizes 
existing studies on the effect of litigation on firm value. Section 3 presents a stylized model of the effect of litigation on plaintiffs and defendants. I derive several hypotheses on the impact of litigation on firm performance. Section 4 contains the empirical analysis, starting with an argument for credit rating as a measure for firm performance, followed by the the estimation approach, a data description and the descriptive analysis. I then present the matching procedure and terminate with the estimation results and some robustness checks. Section 5 summarizes the main findings and concludes.

\section{Previous Empirical Literature}

Most empirical contributions focusing on the private costs of patent litigation make use of stock market data and apply event study methods. The basic concept of the event study methodology in the context of patent infringement suits is that new information contained in the beginning or termination of patent infringement litigation leads the market to update its expectations about future profits and to accordingly adjust the stock market value of the firm. Abnormal stock returns are then attributed to the litigation effect and used to quantify the effect of litigation on the market value of the firm.

Bessen and Meurer (2008b) estimate the expected private costs of patent litigation filing by using the event study methodology. Their sample obtained from Derwent's LitAlert database covers most patent lawsuits filed against US public firms from 1984 to 1999. They find that the cumulative abnormal returns around the filing date of the cases show a loss of $0.62 \%$ of the stock market value for alleged infringers. The effect for patentee litigants is $-0.38 \%$. The expected joint loss to the litigating parties is therefore negative. Considering factors influencing the abnormal returns, Bessen and Meurer find patentee litigants with high liabilities relative to assets to have more negative returns. They further find that belonging to different industries increases the loss in stock market value for the alleged infringer, that small infringers suffer larger losses, and that being sued by a new public firm litigant makes alleged infringers better off. They find some limited evidence that R\&D intensive firms are affected by more negative returns.

Using a small sample of 65 pairs of plaintiffs and defendants involved in lit- 
igation in the information technology industry Raghu et al. (2008) estimate that the filing of patent infringement litigation has negative effects for the stock market of the defendant firm, but positive effects for plaintiff firms. The combined abnormal returns for the plaintiff and defendant firms are found to be negative.

Using a small sample of 108 Taiwanese patent litigation suits in the electronic industry Wang et al. (2010) find that patent litigation negatively affects the prices of the defendants' underlying stocks. Marco (2005) compares market responses to patent litigation ruling in 475 US patent litigation cases to market responses to the particular patent's grant und finds that the resolution about invalidity or infringement is worth as much as the initial patent grant.

Using data on 355 corporate lawsuit filing and settlement announcements in the Wall Street Journal 1981 to 1983, including patent litigation, Bhagat et al. (1994) estimate the stock-market reactions to inter-firm litigation. The market reaction to the filing of the 20 patent infringement cases included in their database shows that in the 2-day window ending on the day the case appears in the Wall Street Journal, the combined market value of the plaintiff and defendant falls on average -3.1 percent.

Focusing on US biotech firms between 1980 and 1992 Lerner (1995) finds for the 26 litigation cases occuring within that period that in the same 2-day window the combined market-adjusted change in market value of plaintiff and defendant falls by two percent.

The major difference of these contributions to my approach is the fact that they use stock market data instead of credit rating information. In addition to this they mostly look at the effect of litigation filing while I differentiate between the effect of the different outcomes of trial.

\section{Theoretical considerations and hypotheses}

In order to understand how patent litigation may affect the involved plaintiffs and defendants I start by summarizing the main features and specificities of the German patent litigation system. As the outcome of the trial case is the most crucial factor for the effect of litigation on the value of a firm, affecting the market shares and economic freedom of the plaintiff and defendant, I then present a simple scheme of the basic effects of different trial outcomes on the 
involved plaintiffs and defendants. In the subsequent section I relax some of the assumptions of the model and discuss how further factors may affect the reaction of the litigator's performance to litigation.

\subsection{The German Patent Litigation System}

A granted patent, coming from a German patent application or from a Germanydesignated European Patent Office (EPO) application, becomes national law. If the patentee or one of his licensors suspects the infringement of the patent by another firm or an individual, he can send an official warning to the infringer (caution), asking him to stop infringing the patented invention and to provide a legally binding "cease and desist" declaration. If the defendant does not react, the plaintiff may file a suit that is aimed at declaring and prohibiting the infringement as well as defining the damages to be paid to the patentee/licensee. The defendant may be required to destroy produced goods that use the disputed technology. The major difference of the German system compared to most other systems is the practice of bifurcation, the separation of nullity and infringement decisions. While patent infringement cases are dealt with by the district courts, decisions about the nullity of a patent are dealt with at the German Federal Patent Court. In an infringement suit the patent is generally assumed to be valid and the decision made concerns only the infringement action. The threat of a nullification of the disputed patent is thus less prevalent than in most other countries such as the US. It is however possible and common practice for the defendant to file a nullity suit at the Federal Patent Court as a defense to the infringement suit. In this case, given that the nullity suit has some chance of success, the district courts will sometimes defer their decision until the nullity suit has been decided. Usually however, the invalidity suit is not decided yet when a decision about infringement is rendered. The delayed decision of invalidity trials at the German Patent Court connected to infringement trials at the district courts is frequently referred to as injunction gap or injunction trap, hinting at the temporal incongruities of these interconnected trials. A visalization of this can be found in Appendix 7.2. Given that an additional trial with new costs risks has to be opened by the defendant the hurdle to file a nullity claim is much higher than in systems without bifurcation. The risk for the patent owner of 
losing the monopoly rights thus still exists, but only through an indirect link. The losing party is obliged to pay the attorney fees of the winning party and the court costs. The attorney and court fees are being calculated according to a formula based on the estimated value of the dispute. For a detailed overview on the infringement proceedings in Germany please refer to European Patent Office (2010), Busche et al. (2010), Pitz (2010) and Stauder (1989).

\subsection{A Simple Model of the Effect of Litigation on Plaintiff and Defendant}

The following scheme depicts in a stylized way the pre- and post-trial payoffs from using the patented technology for the plaintiff and defendant. I suppose that there are only two firms producing a similar product with the technology, which is claimed to be patent protected by the patentee. Prior to litigation the market is split between the two firms, such that both obtain a payoff of $1 / 2 \mathrm{~V}$, the profit to be obtained from that particular product in the German market. $V$ denotes the overall profit to be obtained from the market, $D$ denotes the damages to be paid by the defendant in case of losing and $C$ denotes the trial costs. $P$ stands for the expected probability of the plaintiff prevailing in trial. I assume the decision by the court to be rendered immediately such that there are no costs of delay or business disruption and I assume that no decision about the validity of the patent will be involved. 
Table 1: Payoff Patentee

\begin{tabular}{l|c|c|c}
\hline \hline Payoff & Win & Loss & Settlement \\
\hline Pre-litigation & $\frac{1}{2} V$ & $\frac{1}{2} V$ & $\frac{1}{2} V$ \\
\hline Post-Litigation & $V+D$ & $\frac{1}{2} V-C$ & $S>=p(V+D)+(1-p)\left(\frac{1}{2} V-C\right)$ \\
\hline$\Delta$ Payoff & $\frac{1}{2} V+D$ & $-C$ & $-C<\Delta$ Payoff $<\frac{1}{2} V+D$ \\
\hline \hline
\end{tabular}

Table 2: Payoff Defendant

\begin{tabular}{l|c|c|c}
\hline \hline Payoff & Win & Loss & Settlement \\
\hline Pre-litigation & $\frac{1}{2} V$ & $\frac{1}{2} V$ & $\frac{1}{2} V$ \\
\hline Post-Litigation & $\frac{1}{2} V$ & $0-C-D$ & $S<=p(0-C-D)+(1-p)\left(\frac{1}{2} V\right)$ \\
\hline$\Delta$ Payoff & 0 & $-C-D-\frac{1}{2} V$ & $-C-D-\frac{1}{2} V<\Delta$ Payoff $<0$ \\
\hline \hline
\end{tabular}

Prior to litigation the payoff for both will be $\frac{1}{2} V$ as the market is split equally between the two firms. If the plaintiff wins the trial, meaning that infringement is declared and damages are awarded, the payoff after litigation comprises the entire market $(V)$ as the defendant has to render his share of the market to the plaintiff plus the damages obtained from the defendant to cover lost profits $(D)$. Compared to the pre-trial situation the plaintiff thus improves by $\frac{1}{2} V+D$. When losing in trial the plaintiff obtains a similar payoff as prior to trial which is the duopoly payoff $\frac{1}{2} V$. As the losing party also has to cover the trial costs the overall payoff is $\frac{1}{2} V-C$ which downgrades the plaintiff's situation by $-C$ compared to the pre-trial setting. In case of a settlement the payoff lies in between the payoff obtained from winning and the payoff obtained from losing in trial, depending on the probability of the plaintiff prevailing in trial. As trial costs $C$ are rather small compared to damages ${ }^{1}$ and the profit that can be obtained from the patent, the plaintiff's payoff from settlement will usually make him better off compared to the pre-trial setting. This is due to the little risk the plaintiff has when entering into trial in this simplified model. The only risk is the risk of having to cover the trial costs when losing.

$\overline{1}$ For a jurisdictional value of 2 million Euros the overall trial costs are 100000 Euros and include court costs and lawyer costs for both parties (Meissner Bolte 2012). See Harhoff $(2009$, p. 31) for a comparison of countries. 
Given that trial costs are rather negligible compared to the other costs such as damages, it becomes clear that the average effect of litigation on plaintiffs should be positive.

The situation for the defendant is different. If he wins the pre-trial situation is unchanged as the two firms keep sharing the market. If, however, he loses in trial he has to give up his share of the market, pay damages and cover the trial costs, which makes him definitely worse off. In case of a settlement deal the best case would be a payoff as in case of a victory which leaves the pre-trial situation unchanged. All other possible settlement deals make the defendant worse off compared to the pre-trial setting.

This very simplistic setting demonstrates that the plaintiff is generally at an advantage as he has far less to lose from trial than the defendant. In two out of three possible outcomes (win and settle) the plaintiff is likely to improve his situation, whereas a loss will only result in comparatively little costs. The defendant on the contrary is likely to worsen in two out of three possible outcomes (loss and settle) and to not experience any change in case of winning. This leads to the following hypotheses:

Hypothesis 1: The average effect of litigation on defendants is expected to be negative, while the average effect on plaintiffs is expected to be positive.

Hypothesis 2: A loss or a settlement outcome negatively affects the firm value of the defendant while winning keeps his firm value unchanged. A loss is expected to have a more severe impact than a settlement outcome.

Hypothesis 3: A victory or a settlement outcome positively affects the firm value of the plaintiff while losing keeps the firm value unchanged.

\subsection{The Role of Uncertainty}

The above model abstracts from some important features of patent litigation reality to stress the main effects expected from the different outcomes of litigation. I will now consider additional factors affecting firm value that come into play when relaxing two of the model assumptions. The first assumption 
that needs to be relaxed is that the court immediately renders a decision. This assumption implies that there are no costs of delay or business disruption and that the business partners of the involved firms do not take notice of the trial. In reality the average patent litigation trial however takes almost 1 year. During this period the involved firms and their business partners face uncertainty about outcome and costs of the trial. This may lead to interrupted business activities; taking out a loan may become more difficult and the distraction of management may result in inefficient investments (Bhagat et al. 1994). The empirical literature on financial distress suggests that these costs are substantial $^{2}$. A firm's ability to deal with business disruption and financial or economic distress depends on its overall size, experience and diversification of risk. As suggested by previous literature on patent litigation I expect small firms to be affected more severely by litigation than larger firms due to less financial flexibility. I expect this effect to be more pronounced for defendants as these are the ones that may be faced with a preliminary injunction and the risk of no longer being able to use a technology, which may alter their business partner's willingness to sign business contracts. I further expect firms with prior experience in IP disputes to be able to deal with uncertainty and distress more easily which should be reflected in repeat litigators being better off from litigation than first-time litigators. Regarding the diversification of risk I expect the impact of uncertainty costs to be more pronounced if a patent is particularly important to the business of the patentee or infringer. The stakes in the case will be measured in three different ways. The first measure differs for plaintiffs and defendants: For defendants it is dummy variable indicating whether the defendant is a trader rather than a producer of goods using the patented technology. It is supposed to capture whether the defendants production facility depends on the disputed technology and may have to pause during trial or may have to be changed when losing the case. For the plaintiffs I build a similar measure that indicates whether the plaintiff is a simple licensee compared to being the patentee himself or the exclusive licensee. The stakes for patentees or exclusive licensees are expected to be much higher than for a firm that is a licensee among numerous other licensees. The second

${ }^{2}$ In their case study Cutler and Summers (1988) examine capital-market reactions to different events in the lawsuit Pennzoil vs. Texaco and show that for every dollar Texaco lost, Pennzoil gained only 17 cents. They attribute this to the financial distress imposed on Texaco by the lawsuit (Bhagat et al. 1994). 
measure relates the value at stake to the overall turnover of the firm. If the relative importance is small, the effect of litigation is expected to be small as well, whereas a firm that highly relies on the disputed technology should be affected more severely. The third measure of the involved stakes is the number of fellow plaintiffs or defendants. These considerations lead to the next three hypotheses.

Hypothesis 4: The effect of litigation is more severe for small firms.

Hypothesis 5: Repeat litigants have an advantage in coping with litigation compared to first time litigants.

Hypothesis 6: Parties with lower stakes are affected less severely by litigation than parties with high stakes in the case.

\subsection{The Role of Nullity Suits}

The second model assumption that needs to be relaxed is that no decision about the validity of the patent will be involved, such that the plaintiffs overall risk in the case is rather small. The bifurcation system in Germany is characterized by an indirect link of infringement and nullity trials. Though infringement trials generally assume the disputed patent to be valid it is possible for the defendant to file an invalidity suit at the German Patent Court as an act of defense to the accusation of infringement (Again see Appendix 7.2 for a flowchart of the process). The possibility of filing a nullity suit shifts some of the risk to the plaintiff that suddenly may be faced by the threat of losing his monopoly right. The nullity suit filed at the German Patent Court can either be allowed or rejected. If rejected the defendant faces the court costs for this additional trial, and the infringement trial continues as before. If the nullity suit is accepted there are two options: Either the infringement trial continues as usual and the decision about validity is delivered ex post or, in high doubt of the validity of the patent, the infringement trial is put on hold until the validity question has been resolved. In the first case the infringement trial is not disturbed by the validity decision and the firm value of the firms will not yet be affected by any validity decisions, but only by the outcome of the infringement trial. If the infringement trial is delayed until the decision about 
the validity of the patent and the patent is declared invalid the infringement suit will be dropped. In this case the plaintiff loses his monopoly right and has to cover the trial costs. Interviews with lawyers and anecdotal evidence suggests that putting a case on hold for the nullity proceedings rarely happens. This implies that in most cases the nullity suit should not have an immediate impact on the firm value of the plaintiff. If however a patent is (partially) invalidated while the infringement trial is put on hold this should negatively affect the firm value of the plaintiff. The plaintiff then has to cover the trial costs and accept the loss of his monopoly right. As I am able to match the litigated patents to a database from the German Patent Office, containing all invalidity trials at the German Patent Court, I am able to identify whether a patent has been partially or entirely invalidated during the infringement trial. As expected this rarely happens. For thirty percent of the cases a nullity suit is filed, which results in a (partial) invalidation in 20 percent of the nullity suits (6 percent of all cases) ${ }^{3}$. However, I observe an invalidation that is decided upon during the proccedings of the infringement suit for only 13 of our observations, which is less than 1 percent of all cases. I expect the rare event of nullification during trial to significantly affect the firm value of the plaintiff.

Hypothesis 7a: If a nullity suit comes up during trial and the patent is (partially) invalidated while the infringement case is put on hold the firm value of the plaintiff is negatively affected.

Hypothesis 7b: On the contrary I expect a positive effect for the defendant that will profit in form of a win in trial or a very favorable settlement deal if the patent is invalidated during trial.

\footnotetext{
3 All other nullity suits are either abandoned because of a settlement deal or the patent has been upheld. The data provided by the German Patent Office unfortunately does not distinguish between these 2 options.
} 


\section{Empirical Analysis}

\subsection{Credit Rating as Approach to Measure the Private Value of Intellectual Property}

Empirical studies so far have estimated the impact of litigation by using the market value approach. The classical market value approach introduced into the innovation literature by Griliches (1981) and put forward extensively by Hall(2000) and Hall et al. (2005) is based on the idea that the private returns to innovative activity can be measured via the market value of that firm ${ }^{4}$. The advantage of the market value approach is that data is available on a daily basis and changes can thus be identified precisely using the event study methodology. The most severe drawback is that it is only feasible for firms listed in the stock market which reduced the size of the sample. For Germany where only a small share of all firms is listed in the stock market, such a sample would not be representative for the entire economy.

To address this shortcoming I follow Czarnitzki and Kraft (2004, 2007) who have first used credit rating data for German firms to analyze the impact of innovation activities on firm value. Credit rating information is available for almost every firm looking for bank loans or supplier credits and thus covers a much broader range of companies. While stock market data is associated with the market's expectation of future profits and may well be affected by shortterm fluctuation in shareholder confidence, credit rating information is based on the evaluation of default risk by a rating agency that rates basically all German firms. The German credit rating agency Creditreform provides credit rating data calculated based on business and financial risks, such as industry characteristics, competitive position, management, productivity, profitability, liquidity as well as financial policy and flexibility. "Thus a rating reflects both currently observable firm characteristics and expectations regarding future developments"(Czarnitzki and Kraft 2004, p. 378), which makes it suitable as a proxy for changes in firm value or performance. The index takes values from 100 to 600 , with 100 being the best possible rating and 600 denoting default and insolvency procedures.

\footnotetext{
${ }^{4}$ For papers that have analyzed the market value of patent applications and grants see for example Austin (1993) and Darby et al. (2004)
} 


\subsection{Estimation Approach}

Given the theoretical considerations and the advantages of using changes in credit rating data as a proxy for changes in firm performance, the idea of the empirical approach is to analyze the impact of being involved in patent litigation on the credit rating of the firm. This is the difference between the rating of a firm having been involved in litigation and the rating of that firm in case of not having been involved in litigation. The main challenge for this empirical methodology is the estimation of the so-called counterfactual situation, the rating of the firm had it not been involved in litigation. As factors affecting the litigation probability are at the same time affecting the future firm performance, the treatment (being involved in litigation) is an endogenous variable in the estimation of firm performance. The econometric literature on treatment effects suggests a number of methods that can be applied to control for this endogeneity problem (Blundell and Costa-Dias 2009). I will apply the conditional difference-in-difference estimator, a mixture of the matching method and the difference in difference estimator, in this paper. The DiD estimator is estimated as the difference between the outcome of the treated firm after the treatment and the outcome of the treated firm prior to its treatment. In order to control for general macroeconomic changes a second difference is calculated between the outcome of a non-treated control sample observed for the same time period that matches with respect to a set of observable characteristics that affect the selection into treatment. The difference in rating between the treatment group and the matched group of twin firms can then be attributed to the litigation effect. A detailed description of this estimator can be found in the Appendix.

\section{$4.3 \quad$ Data}

This paper is based on firm-level patent litigation data of German firms. The underlying patent litigation database comprises litigation court records covering about $80 \%$ of all patent litigation cases filed in Germany between 2000 and 2008. As no centralized register exists this comprehensive database has been collected manually by going into the archives of the three major patent litigation courts in Germany. For this analysis the most relevant information 
available in this database is the identity of plaintiffs and defendants, the patent number of the litigated patents, the start and end date and the outcome of trial. I further use information on the value of the court case and the relationship of the involved plaintiffs and defendants to the disputed patent.

The litigation trials handle disputes about the infringement of German patents that can arise between German and foreign firms active in the German market. I restrict the analysis to German firms involved in litigation as plaintiffs or defendants as firm level data and credit rating information is available for Germany only.

These firms have been matched to the Mannheim Enterprise Panel, a biannual panel data set of firms located in Germany maintained at ZEW in cooperation with Creditreform, the largest business information service in Germany. The Mannheim Enterprise Panel contains detailed firm data, amongst others, on employment, sales, legal form, founding date, sectors, bankruptcy events and the credit rating. The Mannheim Enterprise Panel has been matched to patent applications at the European Patent office such that I can construct a patent stock variable for each firm as well as the distribution of the patent stock across six broad technology areas. In addition to providing firm information for firms involved in litigation the Mannheim Enterprise Panel is also used as basis for the control group.

\subsection{Descriptives}

The unit of analysis is a firm-trial case observation, a firm involved in a particular court case as either plaintiff or defendant. After dropping those cases starting prior to 2001, where no rating information was available yet, I obtain 4243 firm-trial observations for the period 2001 to 2008. These observations involve 2406 firms. Before starting a detailed description of the database used I have to pay close attention to the possibility that a firm may be involved in different trials that overlap with respect to the time frame of the trials. A firm can obviously be involved in several trials at the same time that either start or end in the same year or just overlap for some of the trial time. If this is the case changes in rating cannot unambiguously be attributed to one particular trial case and its outcome. 538 out of the 2406 firms involved in litigation are involved in multiple overlapping trials at once. I chose to ex- 
clude those overlapping firm-trial observations from the database in order to reduce the blurring effect of confounding parallel trials ${ }^{5}$. I need to keep in mind that by doing so I exclude the very litigious firms that are constantly involved in patent litigation trials and thereby no longer analyse the entire population of litigation cases. This restriction reduces the database to 2171 firm-trial observations. For 1558 of those observations I observe the change in credit rating from half a year prior to trial to half a year after the end of trial. This database then contains 1432 different firms and 1244 court cases, indicating that firms can appear multiple (non-overlapping) times and one trial case can appear in combination with different firms, which can be different plaintiffs or defendants.

The dependent variable of interest is the change in credit rating half a year after trial compared to half a year prior to trial. This variable compares the valid credit rating of a firm shortly after trial has ended to the last valid pretrial rating that is observed within the 6 month prior to trial. As credit rating is defined on a scale from 100 to 600 , with 100 indicating the best and 600 the worst possible rating, a positive delta can be interpreted as a worsening of the rating while a negative delta indicates an improvement of the rating ${ }^{6}$. Table 3 summarizes the change in rating for all firm-trial observations and distinguishes between plaintiffs and defendants as well as the different outcomes of trial. I see that on average the rating increases by 9.6 rating points, which indicates a worsening of the rating. Looking at plaintiffs and defendants separately I find that the change in rating differs significantly between plaintiffs and defendants. The rating for defendants increases by 12.2 points while the rating for plaintiffs increases by only 5.4 points. This difference is statistically significant at a $5 \%$ significance level. When taking into account the outcome of trial, which can be a victory, a loss, a settlement or a partial victory/loss, I find that the change in rating varies with respect to the outcome of trial. While the differences across outcomes are not significant in the group of plaintiffs there are highly significant differences between winning and losing in the

5 This excludes $22 \%$ of the firms involved in litigation.

6 The rating is available to us on a half-yearly basis, such that we obtain the most recent rating every 6 months. If there is no change in rating the previous rating is reported as it does not lose validity. The rating of a firm is updated upon request and adapted every time one of the input values (such as expected turnover, order situation) changes. Larger firms are also researched without request on a regular basis. 
group of defendants.

Table 3: Observed Change in rating for all firm-trial observations

\begin{tabular}{|c|c|c|c|c|c|}
\hline Change in rating & Observations & Mean Change in Rating & Std. Dev. & Min & $\operatorname{Max}$ \\
\hline All firm-trial observations & 1558 & 9.6 & 58.0 & -248.0 & 398.0 \\
\hline All Plaintiffs & 597 & 5.4 & 45.6 & -200.0 & 395.0 \\
\hline All Defendants & 961 & 12.2 & 64.4 & -248.0 & 398.0 \\
\hline Plaintiff Win & 136 & 7.0 & 34.9 & -86.0 & 264.0 \\
\hline Plaintiff Loss & 122 & 3.6 & 46.0 & -200.0 & 307.0 \\
\hline Plaintiff Settlement & 294 & 5.2 & 49.4 & -199.0 & 395.0 \\
\hline Plaintiff Partial Win & 45 & 7.4 & 48.6 & -100.0 & 266.0 \\
\hline Defendant Win & 131 & 2.0 & 48.0 & -120.0 & 328.0 \\
\hline Defendant Loss & 235 & 16.0 & 67.7 & -103.0 & 396.0 \\
\hline Defendant Settlement & 507 & 13.6 & 65.8 & -115.0 & 398.0 \\
\hline Defendant Partial Loss & 87 & 9.2 & 67.7 & -248.0 & 375.0 \\
\hline
\end{tabular}

\subsection{Matching Procedure}

As I do not know whether the worsening of the rating that I observe is due to the litigation effect or due to an overall trend that applies to all firms I need to compare the change in rating to a control group of similar firms observed for the similar time period. The goal is therefore to apply a difference in difference approach that compares the change in rating of each litigating firm to the change in rating of a similar firm over the same time span. This "twin firm" should exhibit a similar ex-ante probability of being involved in litigation as the firm actually involved in litigation. This means that when chosing that firm I need to consider the literature on firm-level drivers of litigation: There are currently only two contributions investigating the driving factors of litigation at the firm level. These are Bessen and Meurer (2005) and Ziedonis (2003) focusing on patent litigation among semiconductor companies. Bessen and Meurer (2005) show that the size of the firms, the number of patents held by potential plaintiffs, the $R \& D$ performed by prospective defendants, the capital intensity of the parties, and the technological distance between the parties matter for the litigation likelihood. The likelihood of being involved in trial as alleged infringer increases with the R\&D spending of a firm, indicating that fuzzy patent boundaries can make firms unintended infringers. Ziedonis (2003) finds that firms involved in litigation are characterized by larger patent portfolios, numbers of employees and sales. The results by Bessen and Meurer 
and Ziedonis indicate that size, patent portfolio, R\&D expenditures, market value and technology area all matter for the litigation decision and should thus be used for the matching procedure. As R\&D expenditures are not available in the Mannheim Enterprise Panel I use patents as a proxy and instead of market value I use the credit rating.

In order to obtain "twin" firms I proceed in two steps: In a first step I use the Mannheim Enteprise Panel to draw a stratified control group for the litigating firms. This is done to reduce the large database of more than 20 Million observations to a more manageable size. The second step then uses this stratified control group to conduct a propensity score matching that will yield one control observation for each litigation observation.

\subsubsection{Step 1: Stratified control group}

I refer to the Mannheim Enterprise Panel and start by drawing a stratified control group in order to reduce the large sample of potential control firms. For each of the 1558 firm-trial observation I draw 50 control firms ${ }^{7}$ that match, for the same year as the litigation firm, with respect to legal form, a broad firm size category, industry (as measured by 2 digit WZ-codes) and a dummy indicating whether the firm owns EPO-patents. For these control firms I extract credit rating information for the same time span as for their corresponding litigating firms, such that the change in rating can be compared between treated and non-treated firms observed for the exact same time period. The variables used for the pre-selection of potential controls are defined as follows:

- Legal form of the firm is variable indicating the form of organization of he firm, wich can be for example a limited liability company, a general partnership, or a corporation.

- Firm size range is categorical variable dividing the firms with respect to their pre-trial number of employees in 10 different size categories $(<10,1-19$, 20-49, 50-99, 100-249, 250-499, 500-999, 1000-9999, 10000-49999, >=50000).

- Industry classification is the industry classification as measured by 2 digit WZ-2008-codes.

\footnotetext{
7 Note that for many firms I found less than 50 potential controls such that the control group size is not equal to $50 * 1558$. However, for $95 \%$ of all firms I was able to find at least 20 potential control firms.)
} 
- $\boldsymbol{E P}$ Dummy is a dummy indicating whether the firm owns EPO-patents.

Table 4 and 5 compare the litigating firms, distinguishing between plaintiffs and defendants, to their samples of potential control firms with respect to the observed change in credit rating, the pre-trial rating, the size as measured by employees, and the technology distribution of the firm's patent stock. While there is obviously no significant difference with respect to the set of variables used for stratifying the group of potential controls (not reported) I find that the average patent stock, the size of the companies and particularly the pretrial rating differ significantly. When conducting a matching to obtain a more similar control sample the most important factor will be matching on the pretrial rating as the treatment group, both for plaintiffs and defendants, exhibits an about 15 rating points better rating than the control group.

The variable of interest, the change in rating, differs between the plaintiff and defendants and their respective potential control groups. The difference is only significant for the group of plaintiffs compared to their potential control group. While the rating increases by 8.9 points for the potential control group it only increases by 5.4 points for the plaintiffs, indicating that plaintiffs on average profit from litigation. At this point of the analysis I find a significant treatment effect of being involved in litigation as plaintiff, but no effect for defendants. 
Table 4: Comparison of defendants and their potential control group

\begin{tabular}{|c|c|c|c|c|c|c|c|c|c|}
\hline \multirow[b]{2}{*}{ Variable } & \multicolumn{4}{|c|}{$\begin{array}{c}\text { Defendants } \\
\mathrm{N}=961\end{array}$} & \multicolumn{4}{|c|}{$\begin{array}{l}\text { Potential Controls } \\
\qquad \mathbf{N}=\mathbf{3 6 9 2 8}\end{array}$} & \multirow{2}{*}{$\begin{array}{l}\text { p-value of two- } \\
\text { sided test on } \\
\text { mean differences }\end{array}$} \\
\hline & Mean & Std. Dev. & Min & $\operatorname{Max}$ & Mean & Std. Dev. & Min & $\operatorname{Max}$ & \\
\hline L2_employees & 1215.7 & 10857.6 & 1.0 & 194982.0 & 383.5 & 5201.5 & 1.0 & 362063.0 & 0.0 \\
\hline Patent stock & 6.4 & 40.0 & 0.0 & 930.8 & 1.8 & 25.6 & 0.0 & 3941.5 & 0.0 \\
\hline L2_Credit_Rating & 223.1 & 51.7 & 100.0 & 600.0 & 237.4 & 70.4 & 100.0 & 600.0 & 0.0 \\
\hline Age & 27.8 & 31.1 & 1.0 & 208.0 & 28.8 & 36.6 & 0.0 & 1004.0 & 0.3 \\
\hline Share_Electrical_Engineering & 0.1 & 0.3 & 0.0 & 1.0 & 0.1 & 0.2 & 0.0 & 1.0 & 0.0 \\
\hline Share_Instruments & 0.1 & 0.2 & 0.0 & 1.0 & 0.0 & 0.2 & 0.0 & 1.0 & 0.6 \\
\hline Share_Chemistry & 0.1 & 0.2 & 0.0 & 1.0 & 0.0 & 0.2 & 0.0 & 1.0 & 0.1 \\
\hline Share_Process_Engineering & 0.1 & 0.2 & 0.0 & 1.0 & 0.1 & 0.2 & 0.0 & 1.0 & 0.1 \\
\hline Share_Mechanical_Engineering & 0.1 & 0.2 & 0.0 & 1.0 & 0.1 & 0.3 & 0.0 & 1.0 & 1.0 \\
\hline Share_Consumption & 0.0 & 0.2 & 0.0 & 1.0 & 0.0 & 0.1 & 0.0 & 1.0 & 0.0 \\
\hline $\mathrm{P}(\mathrm{X})$ & 0.0 & 0.0 & 0.0 & 0.1 & 0.0 & 0.0 & 0.0 & 0.5 & 0.0 \\
\hline Change in credit rating & 12.2 & 64.4 & -248.0 & 398.0 & 10.8 & 60.9 & -409.0 & 473.0 & 0.5 \\
\hline
\end{tabular}


Table 5: Comparison of plaintiffs and their potential control group

\begin{tabular}{|c|c|c|c|c|c|c|c|c|c|}
\hline \multirow[b]{2}{*}{ Variable } & \multicolumn{4}{|c|}{$\begin{array}{c}\text { Plaintiffs } \\
\mathrm{N}=597\end{array}$} & \multicolumn{4}{|c|}{$\begin{array}{l}\text { Potential Controls } \\
\qquad \mathbf{N}=\mathbf{2 1 3 5 7}\end{array}$} & \multirow{2}{*}{$\begin{array}{l}\text { p-value of two- } \\
\text { sided test on } \\
\text { mean differences }\end{array}$} \\
\hline & Mean & Std. Dev. & Min & $\operatorname{Max}$ & Mean & Std. Dev. & Min & Max & \\
\hline L2_employees & 499.5 & 2608.7 & 1.0 & 43265.0 & 167.0 & 823.9 & 1.0 & 50000.0 & 0.0 \\
\hline Patent stock & 15.4 & 81.3 & 0.0 & 1513.4 & 3.7 & 42.8 & 0.0 & 3620.7 & 0.0 \\
\hline L2_Credit_Rating & 218.5 & 57.0 & 100.0 & 600.0 & 233.1 & 67.0 & 100.0 & 600.0 & 0.0 \\
\hline Age & 38.3 & 37.1 & 2.0 & 190.0 & 32.1 & 43.2 & -7.0 & 1003.0 & 0.0 \\
\hline Share_Electrical_Engineering & 0.2 & 0.3 & 0.0 & 1.0 & 0.1 & 0.3 & 0.0 & 1.0 & 0.0 \\
\hline Share_Instruments & 0.1 & 0.2 & 0.0 & 1.0 & 0.1 & 0.2 & 0.0 & 1.0 & 1.0 \\
\hline Share_Chemistry & 0.1 & 0.2 & 0.0 & 1.0 & 0.1 & 0.2 & 0.0 & 1.0 & 0.4 \\
\hline Share_Process_Engineering & 0.2 & 0.3 & 0.0 & 1.0 & 0.2 & 0.3 & 0.0 & 1.0 & 0.4 \\
\hline Share_Mechanical_Engineering & 0.2 & 0.3 & 0.0 & 1.0 & 0.2 & 0.3 & 0.0 & 1.0 & 0.9 \\
\hline Share_Consumption & 0.1 & 0.2 & 0.0 & 1.0 & 0.1 & 0.2 & 0.0 & 1.0 & 0.0 \\
\hline $\mathrm{P}(\mathrm{X})$ & 0.0 & 0.0 & 0.0 & 0.4 & 0.0 & 0.0 & 0.0 & 0.5 & 0.0 \\
\hline Change in credit rating & 5.4 & 45.6 & -200.0 & 395.0 & 8.9 & 55.3 & -322.0 & 478.0 & 0.1 \\
\hline
\end{tabular}




\subsubsection{Step 2: Propensity Score Matching}

In order to make sure that the control firms also match with respect to the pre-trial date rating, the exact size, and the structure and size of their patent portfolio I chose to follow a propensity score matching approach. This should yield a control group that does no longer differ to the treatment group with respect to these observables. Using the large sample of control firms already stratified by sector, size, legal form and a patent dummy I conduct two propensity score matchings, one for the plaintiffs and one for the defendants. I do so by estimating two separate probit models for the treatments "plaintiff" and "defendant" as theoretical considerations as well as existing empirical evidence suggests that being involved as plaintiff or defendant is driven by different factors and that plaintiffs and defendants are affected differently by litigation. The variables used to conduct the matching in order to obtain an even more similar control group are defined as follows:

- L2.Credit_Rating measures the rating of the firm prior to the filing date of the court case.

- L2.Employees measures the number of employees prior to the filing date of the court case.

- Age measures the age of the firm in years at the beginning of trial.

- Patent stock measures the firm's patent stock at the time of trial. It is measured by calculation the stock of EPO patent applications of the firm starting from 1978 and by applying a depreciation rate of $15 \%$.

- Technology distribution measures the the technology distribution of the firm's patent stock over the 6 technology classes Electrical Engineering, Instruments, Chemistry, Process Engineering, Mechanical Engineering and Consumption. 


\section{Matching Protocol}

(1) Specify and estimate probit models to obtain the propensity scores $P(\hat{X})$

(2) Restrict sample to common support (if common support is small, matching is not applicable)

(3) Choose one observation from subsample of treated firms and delete it from that pool

(4) Calculate Mahalanobis distance between this firm and all non-treated firms in order to find most similar control observation: $\left.M D_{i j}=\left(X_{j}-X_{i}\right) \Omega^{-1} X_{j}-X_{i}\right)$ where $\Omega^{-1}$ is the empirical covariance matrix of the matching argument $\mathrm{X}$ (in our case the propensity score) based on the sample of potential control firms.

(5) Select observation with minimum distance from remaining sample (selected controls are not deleted from the control group) and additionally matching on the pre-defined stratification categories (industry code, size category, patent dummy, legal form, observed time span)

(6) Repeat steps 3 to 5 for all observations on treated firms

(7) The average effect on the treated = mean difference of the change in rating of matched samples

(8) Sampling with replacement can lead the ordinary t-statistic on mean differences to be biased (neglects appearance of repeated observations). Therefore I need to correct standard errors by applying Lechners (2001) estimator for an asymptotic approximation of the standard errors.

The probit models from the matching procedure can be found in the appendix. Table 6 displays summary statistics after the propensity score matching. There is no longer a statistically significant difference with respect to the matching variables between the group of defendants and the control group. The propensity score $\mathrm{P}(\mathrm{X})$ no longer differs between the two matched groups as it does between the treated firms and their potential control group (see table 2 and $3)$. The change in rating differs between the defendants and the control group such that defendants have a 12.2 point increase of their rating while the selected control group exhibits an increase of 10.1 points only. The difference is therefore 2.1 points, but it is not significantly different from zero. I cannot identify a significant average treatment effect of litigation as a defendant on the credit rating of a firm.

For the plaintiffs (table 7) I also find the control and treatment group to not 
differ significantly with respect to the matching variables, indicating that the matching was successful. The increase in rating however is 8.6 rating points higher for the selected control group compared to the plaintiffs. I therefore find a positive treatment effect for plaintiffs ${ }^{8}$.

Table 6: Comparison of defendants and their selected control group

\begin{tabular}{|c|c|c|c|c|c|}
\hline \multirow[b]{2}{*}{ Variable } & \multicolumn{2}{|c|}{$\begin{array}{l}\text { Defendants } \\
\qquad \mathbf{N}=\mathbf{9 6 1}\end{array}$} & \multicolumn{2}{|c|}{$\begin{array}{l}\text { Selected Controls } \\
\qquad \mathrm{N}=\mathbf{9 6 1}\end{array}$} & \multirow{2}{*}{$\begin{array}{l}\text { p-value of two- } \\
\text { sided test on } \\
\text { mean differences }\end{array}$} \\
\hline & Mean & Std. Dev. & Mean & Std. Dev. & \\
\hline L2_employees & 1215.68 & 10857.55 & 1525.21 & 16020.20 & 0.62 \\
\hline Patent stock & 6.38 & 40.03 & 4.45 & 41.25 & 0.299 \\
\hline L2_Credit_Rating & 223.13 & 51.65 & 221.05 & 52.41 & 0.381 \\
\hline Age & 27.81 & 31.0568 & 29.14 & 32.26 & 0.355 \\
\hline Share_Electrical_Engineering_Patents & 0.10 & 0.26 & 0.09 & 0.26 & 0.794 \\
\hline Share_Instruments_Patents & 0.05 & 0.19 & 0.05 & 0.20 & 0.692 \\
\hline Share_Chemistry_Patents & 0.05 & 0.19 & 0.05 & 0.19 & 0.703 \\
\hline Share_Process_Engineering_Patents & 0.09 & 0.24 & 0.09 & 0.25 & 0.968 \\
\hline Share_Mechanical_Engineering_Patents & 0.09 & 0.24 & 0.09 & 0.25 & 0.703 \\
\hline Share_Consumption_Patents & 0.04 & 0.16 & 0.04 & 0.17 & 0.561 \\
\hline $\mathrm{P}(\mathrm{X})$ & 0.03 & 0.03 & 0.03 & 0.01 & 0.538 \\
\hline Change in credit rating & 12.20 & 64.35 & 10.13 & 54.53 & 0.447 \\
\hline
\end{tabular}

8 Note that for plaintiffs, defendants as well as their matched control groups there is no change in rating for about 40 percent of the observations. 


\begin{tabular}{|c|c|c|c|c|c|}
\hline \multirow[b]{2}{*}{ Variable } & \multicolumn{2}{|c|}{$\begin{array}{l}\text { Plaintiffs } \\
\mathbf{N}=\mathbf{5 9 7}\end{array}$} & \multicolumn{2}{|c|}{$\begin{array}{l}\text { Selected Controls } \\
\qquad \mathbf{N}=\mathbf{5 9 7}\end{array}$} & \multirow{2}{*}{$\begin{array}{l}\text { p-value of two- } \\
\text { sided test on } \\
\text { mean differences }\end{array}$} \\
\hline & Mean & Std. Dev. & Mean & Std. Dev. & \\
\hline L2_employees & 499.47 & 2608.70 & 511.33 & 2502.43 & 0.94 \\
\hline Patent stock & 15.36 & 81.29 & 23.81 & 221.47 & 0.46 \\
\hline L2_Credit_Rating & 218.48 & 57.00 & 217.60 & 59.05 & 0.81 \\
\hline Age & 38.34 & 37.11 & 37.04 & 36.84 & 0.59 \\
\hline Share_Electrical_Engineering_Patents & 0.16 & 0.32 & 0.20 & 0.36 & 0.11 \\
\hline Share_Instruments_Patents & 0.08 & 0.22 & 0.08 & 0.23 & 0.97 \\
\hline Share_Chemistry_Patents & 0.06 & 0.19 & 0.06 & 0.21 & 0.87 \\
\hline Share_Process_Engineering_Patents & 0.17 & 0.31 & 0.15 & 0.31 & 0.28 \\
\hline Share_Mechanical_Engineering_Patents & 0.16 & 0.31 & 0.16 & 0.32 & 0.88 \\
\hline Share_Consumption_Patents & 0.09 & 0.25 & 0.07 & 0.21 & 0.07 \\
\hline $\mathrm{P}(\mathrm{X})$ & 0.03 & 0.02 & 0.03 & 0.01 & 0.26 \\
\hline Change in credit rating & 5.44 & 45.61 & 14.05 & 61.02 & 0.02 \\
\hline
\end{tabular}

\subsection{Disentangling the average treatment effects}

Given the absence of a significant average treatment effect for being involved in litigation as defendant and the positive average treatment effect of being involved in litigation as plaintiff the next step is to try disentangling the average treatment effects with respect to specifics of the firms and the outcomes of trial. I expect significant differences when testing whether the treatment effects I observe vary across trial outcomes and firm characteristics. For doing so I regress the change in credit rating on the entire set of matching variables as well as the treatment variable (defendant or plaintiff). I then interact the treatment effect (defendant or plaintiff) for each observation with the outcomes of trial and with several firm characteristics expected to matter for the change in rating. I estimate separate equations for the plaintiffs and defendants. The estimation method is basic OLS and I cluster the standard errors by firm as some firms appear multiple times in my dataset. I also control for the trial year and the duration of the observed time span as this may affect by how much the rating of both treated and non-treated firms changes. The firm and trial variables used are defined as follows: 
- Loss is a dummy variable taking the value 1 if the party has lost the case and 0 otherwise.

- Win is a dummy variable taking the value 1 if the party has won the case and 0 otherwise.

- Settle is a dummy variable taking the value 1 if the parties have settled the case and 0 otherwise. I interpret dropped cases as settled as interviews with specialized patent attorneys have indicated that parties often drop their case but do not notify the court about a private settlement agreement.

- Partial Loss is a dummy variable taking the value 1 if the defendant has lost some but not all of the claims of the case and 0 otherwise.

- Partial Win is a dummy variable taking the value 1 if the plaintiff has won some but not all of the claims of the case and 0 otherwise.

- $\ln ($ L2.Employees) is a dummy variable taking the value 1 if the party has less than 50 employees.

- Number Parties is an integer variable indicating how many firms are involved in trial at the side of the firm of interest.

- Repeat Litigant is a dummy variable taking the value 1 if the party is involved in trial several times in our database and can thus be considered more experienced in litigation.

- Defendant Trader is a dummy variable taking the value 1 if the defendant is a trader rather than a firm producing goods with the patented technology and 0 otherwise.

- Plaintiff Simple Licensee is a dummy variable taking the value 1 if the plaintiff is one among many licensees rather than the patentee himself or his exclusive licensee.

- Value at stake/turnover is a variable measuring the importance of the case relative to the firms overall turnover.

- Patent invalidated is a variable measuring whether the patent has been invalidated during trial.

In a robustness check I have further included the Jaffe (1986) proximity measure for technological similarity of the patent portfolios of plaintiff and defendant in order to see whether technological closeness alters the overall effect of litigation. As this does not yield any significant results I do not report these estimates due to limitations of space. 


\subsubsection{Defendants}

Table 8 displays the regression results for the defendants. Specification (1) includes the simple treatment variable "defendant", indicating whether the firm was involved in litigation as a defendant or whether it is a control firm. As seen before there is no treatment effect of being involved in litigation as a defendant as such. Specification (2) interacts the defendant dummy with the different possible outcomes of trial, using a victory in trial as baseline category. I find that a loss and a settlement outcome both significantly increase the credit rating of the defendant compared to a win in trial, which corresponds to a worsening of the rating. I find no difference for the outcome partial loss, which may be due to the large degree of heterogeneity in this outcome category. Specification (3) interacts the treatment dummy with the outcomes and five other variables that are expected to have an effect on how a firm's rating reacts to litigation. I again find that a loss and a settlement outcome both significantly increase the credit rating of the defendant compared to a win in trial. While differences across outcomes are already interesting as such, a more meaningful result is a comparison of being involved in litigation with a particular outcome to not being involved in litigation at all. In order to find the overall effect of being involved as a defendant and losing, the coefficients for defendant and loss have to be summed up. The overall effect is 21.9 and an F-test indicates that this differs significantly from zero at the $10 \%$ significance level. Similarly the effect of being involved as a defendant and agreeing upon a settlement deal is 20.4 and also significantly different from zero. I further find that the effect of losing and settling does not differ significantly. When switching the baseline category for the outcomes to loss such that I can obtain a coefficient for a win in trial I find that winning makes defendants significantly better off than losing (as seen before), but I also find that the overall treatment effect of being a defendant and winning compared to not being in litigation is not significantly different from zero. I do find support for hypothesis 2 , stating that a loss and a settlement deal negatively affect the defendant. I do however not find a significant difference between a loss and a settlement deal.

The interaction with the number of employees shows that small defendants are at a disadvantage when involved in litigation. I find the rating of repeat litigants to drop by 7.1 points compared to the rating of first-time litigants 
when being involved in litigation, supporting our hypothesis that repeat litigants are at an advantage in coping with alleged infringement. I further find evidence for hypothesis 6 that focuses on the effect of stake size on the impact of litigation: All three specifications of stake size show the expected effect. Regarding the number of fellow parties accused of infringement in trial I find more parties to coincide with an improvement of the rating, indicating that sharing the risk in trial makes defendants better off. Defendants being traders experience a drop of 7.8 rating points when involved in litigation compared to a producers of goods produced with the patented technology. As production goes along with costly facilities that might be shut down during trial or may become obsolete when losing in trial stakes are generally higher for producers compared to traders. The effect of the relative importance of the case for the litigant as measured by the relation of the value at stake to the firm's overall turnover also supports hypothesis 6 . I further find that a (partial) invalidation of the patent during trial makes the defendant significantly better off, which can be attributed to the defendant profiting from a favorable settlement deal with the plaintiff or a dropping of the case. 


\begin{tabular}{|c|c|c|c|c|c|c|}
\hline & \multicolumn{2}{|c|}{ (1) } & \multicolumn{2}{|c|}{$(2)$} & \multicolumn{2}{|l|}{$(3)$} \\
\hline & Coef. & Std. Err. & Coef. & Std. Err. & Coef. & Std. Err. \\
\hline Defendant & 2.198 & $(2.682)$ & -6.193 & $(4.722)$ & 9.114 & $(7.112)$ \\
\hline Defendant*Loss (baseline: Win) & & & $12.044^{*}$ & $(6.175)$ & $12.742^{* *}$ & $(6.022)$ \\
\hline Defendant*Settle (baseline: Win) & & & $9.466^{*}$ & $(5.193)$ & $11.259^{* *}$ & $(4.954)$ \\
\hline Defendant*Partial Loss (baseline: Win) & & & 4.908 & $(8.338)$ & 6.228 & $(8.176)$ \\
\hline Repeat Litigant & & & & & $-7.056^{*}$ & $(3.995)$ \\
\hline Number of Defendant firms & & & & & $-2.868^{* *}$ & $(1.246)$ \\
\hline Value at stake/turnover & & & & & $0.916^{*}$ & $(0.517)$ \\
\hline Patent invalidated & & & & & $-37.191^{* * *}$ & $(13.262)$ \\
\hline Defendant trader & & & & & $-7.819^{*}$ & $(4.065)$ \\
\hline Defendant*Ln(L2.employees) & & & & & $-2.277^{*}$ & $(1.204)$ \\
\hline L2.Credit Rating & -0.053 & $(0.039)$ & -0.051 & $(0.039)$ & -0.056 & $(0.039)$ \\
\hline Share_ElectricalEng & -11.181 & $(7.823)$ & -10.656 & $(7.721)$ & -11.315 & $(7.760)$ \\
\hline Share_Instruments & $-24.357^{* *}$ & $(10.070)$ & $-23.045^{* *}$ & $(9.879)$ & $-23.486^{* *}$ & $(9.898)$ \\
\hline Share_Chemistry & $-17.439^{* *}$ & $(8.434)$ & $-16.902^{* *}$ & $(8.321)$ & $-17.288^{* *}$ & $(8.316)$ \\
\hline Share_ProcessEng & $-14.309^{* *}$ & $(7.062)$ & $-13.713^{* *}$ & $(6.973)$ & $-16.182^{* *}$ & $(6.956)$ \\
\hline Share_MechanicalEng & -9.617 & $(8.716)$ & -9.481 & $(8.637)$ & -10.143 & $(8.698)$ \\
\hline Share_Consumption & $-17.483^{* *}$ & $(7.972)$ & $-17.438^{* *}$ & $(7.911)$ & $-17.087^{* *}$ & $(7.955)$ \\
\hline Patent stock/L2.employees & -0.094 & $(0.167)$ & -0.111 & $(0.169)$ & $-0.329^{* *}$ & $(0.167)$ \\
\hline EP dummy & 13.089 & $(8.344)$ & 12.729 & $(8.258)$ & 13.042 & $(8.288)$ \\
\hline Age & 0.077 & $(0.068)$ & 0.076 & $(0.068)$ & 0.072 & $(0.068)$ \\
\hline Ln(L2.employees) & $-1.963^{* *}$ & $(0.963)$ & $-1.949^{* *}$ & $(0.960)$ & -0.775 & $(0.933)$ \\
\hline Duration & $3.531^{* * *}$ & $(1.274)$ & $3.566^{* * *}$ & $(1.281)$ & $4.298^{* * *}$ & $(1.373)$ \\
\hline Industry dummies & yes & & yes & & yes & \\
\hline Legal form dummies & yes & & yes & & yes & \\
\hline Year dummies & yes & & yes & & yes & \\
\hline Constant & 86.036 & $(62.847)$ & 85.119 & $(62.062)$ & 84.027 & $(60.491)$ \\
\hline Observations & 1922 & & 1922 & & 1922 & \\
\hline$R^{2}$ & 0.069 & & 0.071 & & 0.085 & \\
\hline
\end{tabular}

Significance: ${ }^{*} \mathrm{p}<0.1,{ }^{* *} \mathrm{p}<0.05,{ }^{* * *} \mathrm{p}<0.01$. Standard errors clustered at the firm level.

\subsubsection{Plaintiffs}

Table 9 display the regression results for the plaintiffs. Specification (1) includes the simple treatment variable "plaintiff", indicating whether the firm was involved in litigation as a plaintiff or whether it is a control firm. Analogously to the descriptive results there is a positive treatment effect of being involved in litigation as a plaintiff: The rating improves by 8.65 rating points 
when the firm is involved in litigation as plaintiff, which supports hypothesis 1 stating that plaintiffs on average profit from litigation. Specification (2) interacts the plaintiff dummy with the different possible outcomes of trial, using a loss in trial as baseline category. I find none of these interaction effects to be able to explain or alter the litigation-induced increase in rating. Hypothesis 3 can not be confirmed. Specification (3) interacts the treatment dummy with five other variables that are expected to have an effect on how the plaintiff's rating reacts to litigation. I do not find support for hypothesis 4 and 5, stressing the effects of experience and size, and I find limited evidence for hypothesis 6 , focussing on the effect of the relative stakes in the court case. Plaintiffs that are simple licensees rather than the patentee or the unique licensee profit more from litigation which indicates that they are affected less by the thread of nullification of the patent. Regarding hypothesis 7 , considering the effect of in-trial invalidation of the disputed patent I do not find that a (partial) invalidation of the disputed patent during the infringement proceedings significantly affects the performance of the plaintiff. This result may however be due to the fact that there are only 3 observations with an invalidation during trial. 


\begin{tabular}{|c|c|c|c|c|c|c|}
\hline & \multicolumn{2}{|c|}{$(1)$} & \multicolumn{2}{|c|}{$(2)$} & \multicolumn{2}{|c|}{$(3)$} \\
\hline & Coef. & Std. Err. & Coef. & Std. Err. & Coef. & Std. Err. \\
\hline Plaintiff & $-8.650^{* * *}$ & $(3.057)$ & $-10.316^{* *}$ & $(5.001)$ & $-28.212^{*}$ & $(14.506)$ \\
\hline Plaintiff*Settle (baseline: Loss) & & & 0.199 & $(5.248)$ & -0.021 & $(5.260)$ \\
\hline Plaintiff*Win (baseline: Loss) & & & 4.395 & $(5.694)$ & 3.776 & $(5.595)$ \\
\hline Plaintiff*Partial Win (baseline: Loss) & & & 7.238 & $(8.554)$ & 7.870 & $(8.820)$ \\
\hline Repeat litigant & & & & & 1.225 & $(5.236)$ \\
\hline Number of Plaintiff firms & & & & & 13.823 & $(11.998)$ \\
\hline Plaintiff simple licensee & & & & & $-10.704^{* *}$ & $(4.863)$ \\
\hline Value at stake/turnover & & & & & -0.043 & $(0.160)$ \\
\hline Patent invalidated & & & & & 24.260 & $(28.342)$ \\
\hline Plaintiff*Ln(L2.employees) & & & & & 1.022 & $(1.351)$ \\
\hline Ln(L2.employees) & -0.771 & $(1.173)$ & -0.744 & $(1.175)$ & -1.391 & $(1.530)$ \\
\hline Patent stock/L2.employees & 0.082 & $(0.081)$ & 0.088 & $(0.082)$ & 0.087 & $(0.088)$ \\
\hline L2.Credit rating & -0.048 & $(0.048)$ & -0.049 & $(0.049)$ & -0.048 & $(0.048)$ \\
\hline EP dummy & -10.466 & $(12.113)$ & -11.089 & $(12.204)$ & -10.801 & $(12.290)$ \\
\hline Share_ElectricalEng & 13.283 & $(13.037)$ & 13.651 & $(13.086)$ & 13.565 & $(13.060)$ \\
\hline Share_Instruments & 1.451 & $(11.945)$ & 1.951 & $(12.002)$ & 1.280 & $(11.925)$ \\
\hline Share_Chemistry & -3.273 & $(12.723)$ & -3.198 & $(12.760)$ & -2.880 & $(12.716)$ \\
\hline Share_ProcessEng & 5.336 & $(10.326)$ & 6.124 & $(10.405)$ & 6.041 & $(10.362)$ \\
\hline Share_MechanicalEng & -2.095 & $(11.134)$ & -1.984 & $(11.166)$ & -2.206 & $(11.085)$ \\
\hline Share_Consumption & 11.854 & $(10.357)$ & 12.444 & $(10.482)$ & 12.134 & $(10.392)$ \\
\hline Age & 0.082 & $(0.052)$ & 0.082 & $(0.051)$ & 0.078 & $(0.051)$ \\
\hline Duration & $6.993^{* * *}$ & $(2.335)$ & $7.010^{* * *}$ & $(2.339)$ & $6.851^{* * *}$ & $(2.421)$ \\
\hline Industry dummies & yes & & yes & & yes & \\
\hline Legal form dummies & yes & & yes & & yes & \\
\hline Year dummies & yes & & yes & & yes & \\
\hline Constant & 22.482 & $(16.185)$ & 21.748 & $(16.411)$ & 22.781 & $(16.855)$ \\
\hline Constant & 22.482 & $(1.39)$ & 21.748 & $(1.33)$ & 22.781 & $(1.35)$ \\
\hline Observations & 1194 & & 1194 & & 1194 & \\
\hline$R^{2}$ & 0.118 & & 0.118 & & 0.122 & \\
\hline
\end{tabular}

Significance: $* \mathrm{p}<0.1, * * \mathrm{p}<0.05, * * * \mathrm{p}<0.01$. Standard errors clustered at the firm level.

\subsection{Robustness Checks}

Though the observed change of the credit rating is a clear signal of or a positive a negative impact of litigation, it is rather difficult to grasp how severe the effect really is and to which degree firms are hurt or profit from litigation. Therefore I now apply a different measure to capture the effect of litigation. 
I define a bankruptcy event as the firm going bancrupt sometime in between the filing of the court case and at the latest 1 year after the end of trial. This measure is based on the exit information in the Creditreform data that indicates whether and when a firm exits for bankruptcy reasons. Using the dummy variable bankruptcy event as dependent variable I estimate two probit models of bankruptcy. I use the same structure as above and again cluster the standard errors at the firm level. The results are displayed as average marginal effects.

\subsubsection{Defendants}

The probabiliy of bankruptcy within the period of trial plus 1 year after the end of trial is 3.9 percent for the control group and 4.2 percent for the defendants. This difference is not significantly different from zero. Table 10 displays the estimation results for the defendants ${ }^{9}$. Overall the effects reflect the previous results obtained when using the change in rating as dependent variable. The average effect of being defendant in litigation is not significantly different from zero, but the bankruptcy probability significantly increases with the defendant losing or settling in trial compared to winning. Additionally, smaller litigants and those with a high value at stake relatively to their turnover are more likely to experience bankruptcy from trial. The bankruptcy probability decreases with multiple defendants involved in trial. These results suggest that litigation does have visible effects on the involved defendants that can go beyond the (maybe rarely visible) change in credit rating.

\subsubsection{Plaintiffs}

The probabiliy of bankruptcy within the period of trial plus 1 year after the end of trial is 4.4 percent for the control group and 2.3 percent for the plaintiffs. This difference is significantly different from zero, indicating that, again, the treatment effect of litigation on plaintiffs is on average positive. Table 11 displays the estimation results for plaintiffs. I find that plaintiffs on average profit from litigation as indicated by a lower bankruptcy probability. This effect increases even more if the plaintiff wins in trial or agress upon a set-

$\overline{9}$ The number of observations reduces as bankruptcy is a rather rare event and does not happen in each of the industry classes. 
tlement deal compared to losing. This is the first time I can actually identify an effect of the outcome of trial for the plaintiffs. The direction of the effect is as expected. Similar to the defendants I also find small firms involved in litigation be be more likely to go bankrupt than larger litigants. The effects of the number of fellow plaintiffs, the plaintiffs relation to the disputed patent and the relative value of the case to the plaintiff are opposite to what I would expect. The bankruptcy probability significantly increases with the number of plaintiffs and the plaintiff being a licensee rather than the patentowner. At the same time the bankruptcy probability significantly reduces with an increase of the relative value of the case to the plaintiff. One explanation for this might be that these parties take more caution because they are particularly aware of potential negative effects from invalidation. The effect of an invalidation of the disputed patent during trial cannot be analyzed as none of the invalidations leads to a bankruptcy event such that the variable has to be ommited in the estimation $^{10}$.

\footnotetext{
${ }^{10}$ Note that the variable partial win is also ommited as none of the plaintiffs with a partial win go bancrupt
} 
Table 10: Probability of bankruptcy- Defendants

\begin{tabular}{|c|c|c|c|c|c|c|}
\hline & \multicolumn{2}{|c|}{$(1)$} & \multicolumn{2}{|l|}{$(2)$} & \multicolumn{2}{|l|}{$(3)$} \\
\hline & Marg. effect & Std. Err. & Marg. effect & Std. Err. & Marg. effect & Std. Err. \\
\hline Defendant & 0.002 & $(0.009)$ & $-0.050^{*}$ & $(0.028)$ & -0.044 & $(0.032)$ \\
\hline Defendant*Loss (baseline: Win) & & & $0.059^{* *}$ & $(0.029)$ & $0.098^{* * *}$ & $(0.031)$ \\
\hline Defendant*Settle (baseline: Win) & & & $0.055^{*}$ & $(0.028)$ & $0.094^{* * *}$ & $(0.030)$ \\
\hline Defendant*Partial Loss (baseline: Win) & & & $0.071^{* *}$ & $(0.033)$ & $0.111^{* * *}$ & $(0.035)$ \\
\hline Repeat litigant & & & & & -0.035 & $(0.033)$ \\
\hline Number defendant firms & & & & & $-0.013^{* *}$ & $(0.006)$ \\
\hline Value at stake/turnover & & & & & $0.003^{* * *}$ & $(0.001)$ \\
\hline Defendant trader & & & & & -0.022 & $(0.015)$ \\
\hline Defendant*Ln(L2.employees) & & & & & -0.005 & $(0.004)$ \\
\hline L2 Credit Rating & $0.001^{* * *}$ & $(0.000)$ & $0.001^{* * *}$ & $(0.000)$ & $0.001^{* * *}$ & $(0.000)$ \\
\hline Share_ElectricalEng & 0.022 & $(0.034)$ & 0.024 & $(0.034)$ & 0.022 & $(0.034)$ \\
\hline Share_Instruments & 0.002 & $(0.043)$ & 0.006 & $(0.043)$ & 0.004 & $(0.041)$ \\
\hline Share_Chemistry & -0.058 & $(0.037)$ & -0.057 & $(0.037)$ & -0.056 & $(0.035)$ \\
\hline Share_ProcessEng & 0.010 & $(0.032)$ & 0.015 & $(0.033)$ & 0.017 & $(0.033)$ \\
\hline Share_MechanicalEng & 0.027 & $(0.035)$ & 0.028 & $(0.035)$ & 0.027 & $(0.035)$ \\
\hline Share_Consumption & -0.036 & $(0.045)$ & -0.034 & $(0.045)$ & -0.037 & $(0.044)$ \\
\hline Patent stock/L2.employees & $-0.077^{*}$ & $(0.044)$ & $-0.086^{*}$ & $(0.050)$ & $-0.064^{* * *}$ & $(0.017)$ \\
\hline EP dummy & -0.029 & $(0.033)$ & -0.033 & $(0.034)$ & -0.033 & $(0.034)$ \\
\hline Age & $0.000^{* * *}$ & $(0.000)$ & $0.000^{* * *}$ & $(0.000)$ & $0.000^{* * *}$ & $(0.000)$ \\
\hline Duration & $0.009^{* *}$ & $(0.004)$ & $0.010^{* * *}$ & $(0.004)$ & $0.010^{* * *}$ & $(0.004)$ \\
\hline Industry dummies & yes & & yes & & yes & \\
\hline Legal form dummies & yes & & yes & & yes & \\
\hline Year dummies & yes & & yes & & yes & \\
\hline Observations & 1638 & & 1638 & & 1629 & \\
\hline
\end{tabular}

Significance: ${ }^{*} \mathrm{p}<0.1,{ }^{* *} \mathrm{p}<0.05,{ }^{* * *} \mathrm{p}<0.01$. Standard errors clustered at the firm level. 


\begin{tabular}{|c|c|c|c|c|c|c|}
\hline & \multicolumn{2}{|c|}{ (1) } & \multicolumn{2}{|l|}{$(2)$} & \multicolumn{2}{|l|}{$(3)$} \\
\hline & Marg. effect & Std. Err. & Marg. effect & Std. Err. & Marg. effect & Std. Err. \\
\hline Plaintiff & $-0.020^{* *}$ & $(0.010)$ & 0.005 & $(0.016)$ & 0.019 & $(0.029)$ \\
\hline Plaintiff*Settle (baseline: Loss) & & & $-0.035^{*}$ & $(0.019)$ & $-0.037^{* *}$ & $(0.019)$ \\
\hline Plaintiff*Win (baseline: Loss) & & & $-0.042^{*}$ & $(0.025)$ & $-0.056^{*}$ & $(0.029)$ \\
\hline Repest litigant & & & & & -0.001 & $(0.025)$ \\
\hline Number of Plaintiff firms & & & & & 0.037 & $(0.024)$ \\
\hline Plaintiff simple licensee & & & & & $0.056^{*}$ & $(0.030)$ \\
\hline Value at stake/turnover & & & & & $-0.431^{* *}$ & $(0.189)$ \\
\hline Plaintiff*Ln(L2.employees) & & & & & $-0.011^{*}$ & $(0.006)$ \\
\hline Ln(L2.employees) & -0.005 & $(0.004)$ & -0.004 & $(0.005)$ & -0.004 & $(0.005)$ \\
\hline Patent stock/L2.employees & -0.019 & $(0.016)$ & -0.024 & $(0.022)$ & -0.034 & $(0.040)$ \\
\hline L2.Credit Rating & $0.001^{* * *}$ & $(0.000)$ & $0.001^{* * *}$ & $(0.000)$ & $0.001^{* * *}$ & $(0.000)$ \\
\hline EP dummy & $-0.066^{* *}$ & $(0.028)$ & $-0.064^{* *}$ & $(0.031)$ & $-0.067^{* *}$ & $(0.033)$ \\
\hline Share_ElectricalEng & $0.070^{* * *}$ & $(0.023)$ & $0.069^{* * *}$ & $(0.025)$ & $0.076^{* * *}$ & $(0.029)$ \\
\hline Share_Instruments & $0.075^{* * *}$ & $(0.026)$ & $0.070^{* *}$ & $(0.028)$ & $0.092^{* * *}$ & $(0.033)$ \\
\hline Share_Chemistry & $-0.421^{* *}$ & $(0.188)$ & $-0.445^{* *}$ & $(0.174)$ & $-0.361^{*}$ & $(0.186)$ \\
\hline Share_ProcessEng & -0.043 & $(0.033)$ & -0.046 & $(0.035)$ & -0.026 & $(0.033)$ \\
\hline Share_MechanicalEng & $0.062^{* *}$ & $(0.025)$ & $0.053^{* *}$ & $(0.026)$ & $0.067^{* *}$ & $(0.028)$ \\
\hline Share_Consumption & $0.054^{*}$ & $(0.029)$ & 0.050 & $(0.033)$ & 0.044 & $(0.032)$ \\
\hline Age & $0.000^{*}$ & $(0.000)$ & $0.000^{* *}$ & $(0.000)$ & $0.000^{* *}$ & $(0.000)$ \\
\hline Duration & $0.013^{* * *}$ & $(0.005)$ & $0.014^{* * *}$ & $(0.005)$ & $0.018^{* *}$ & $(0.007)$ \\
\hline Industry dummies & yes & & yes & & yes & \\
\hline Legal form dummies & yes & & yes & & yes & \\
\hline Year dummies & yes & & yes & & yes & \\
\hline Observations & 878 & & 806 & & 804 & \\
\hline
\end{tabular}

Significance: $* \mathrm{p}<0.1, * * \mathrm{p}<0.05, * * * \mathrm{p}<0.01$. Standard errors clustered at the firm level.

\section{Discussion and Conclusion}

The purpose of this study was to derive predictions on the effect of patent litigation on the firm performance of plaintiff and defendant and to emprically test these by estimating treatment effects of patent litigation.

The results suggest that patent litigation in Germany constitutes a severe threat for alleged infringers. Not only losing a case but also reaching a settlement agreement has a negative impact on the defendant. This might be explainable by a high bargaining power of the plaintiff that can force defendants into settlement: Either plaintiffs are to a large degree correct in their 
presumption of infringement and can demand high settlement amounts to avoid an unfavorable judgment for the defendant or they have a systematic strategic advantage over the defendants. The fact that small, first time defendants are affected more severely by litigation than other firms implies that they have more difficulties in coping with litigation, which can be attributed to their ability to deal with economic and financial distress. With respect to the plaintiffs I show that there seems to be no tax on innovation for the patentee himself: Plaintiffs generally profit from litigation in terms of their credit rating, independent of the outcome of trial.

In a robustness check I then estimate the probability of a bankruptcy event in between the filing date of trial and one year after its closing date. The effects remain robust for the defendants. The estimation for plaintiffs reveals, as before, that plaintiffs on average profit from litigation. It does however additionally show that a victory or a settlement deal has a positive effect for the plaintiff compared to losing in trial, which could not be shown in the prior analysis, but which matches the theoretical considerations.

The fact that I am only able to identify moderating and intensifying factors for the group of plaintiffs in the robustness check using the bankruptcy event rather than the credit rating as dependent variable may be due to several reasons: One reason may be the positive signalling effect of litigation. Being known to sue another firm for infringement can discourage others from entering into the market and improve the firm's position. Given that the rating of a firm is only updated upon request it is possible that the rating increases in expectation of a positive litigation outcome. A negative outcome has a comparatively little effect for plaintiffs as it does not involve the nullification of the patent, this may then not be enough for a request for a new investigation of the firm and a subsequent worsening of the rating. A bankruptcy event however, the most severe consequence for the plaintiff, is in any case reported in the data independent of a request and can thus be related to the trial outcome according to my expectations.

Taking together the study highlights two aspects: Small and inexperienced firms are at a disadvantage when trying to deal with alleged infringement.If litigation is mainly the result of unintended infringement, as suggested by Bessen and Meuer (2008) or plaintiffs' strategies of "being infringed" rather than willful infringement policy makers may think about mechanisms of supporting firms, particularly small and inexperienced firms, in avoiding litiga- 
tion. The so-called ex-post tax on innovation on these small firms is particularly severe as the innovativeness of SMEs is particularly important for the performance of any economy. Suffering from litigation may hamper this innovativeness both through immediate effects from business interruption as well as impaired access to finance.

The second aspect concerns the bifurcated litigation proceedures in Germany. My results nicely reveal the spatial and temporal separation of invalidity and infringement decisions. This split is generally seen to favour plaintiffs/patentees in an infringement action as they are not faced with the direct thread of an invalidation of their patent. With nullity suits frequently being a defendant's most important defense, but taking much longer than an infringement trial, the patentee can expect to win the infringement trial prior to the ruling of the nullity trial. This puts him in a strong position to negotiate a favorable settlement deal. This can also explain the differences in results when comparing this study to studies on the US system: Studies like Bessen and Meurer (2008b) show the expected effect of litigation for plaintiffs to be negative, reflecting the risk that the disputed patents gets invalidated during the infringement proceedings, while I identify a positive realized effect of litigation, reflecting the fact that in Germany patents rarely get invalidated during infringement trials. Infringement judgments may of course later have to be reversed due to invalidation. This produces lots of transaction and opportunity costs and given that innovations are produced and marketed at a very high speed the economic damage resulting from wrong judgments can be immense. A simultaneous decision of both validity and infringement would solve this incongruity and deliver immediate and reliable judgments. This would of course be at the cost of a longer overall duration of the trial. At this point patent quality comes into play. The higher the quality of the patents issued by the patent office the less likely an invalidation of the patent and the less needed an invalidation suit in parallel to an infringement suit.

Of course there are also several shortcomings. Compared to stock market studies that can track developments in firm value for the exact filing date the interval of 6 months in between the publishing of the updated ratings leads to rather rough estimates of the impact of litigation. Also it is not possible to distinguish between wilful infringement, unintended infringement and plaintiffs' strategies of being infringed. 
A Probit Models

Table A1: Probit Model Defendants

\begin{tabular}{|c|c|c|}
\hline & \multicolumn{2}{|c|}{ (1) } \\
\hline & Coef. & t-value \\
\hline Ln(L2.employees) & $0.038^{* * *}$ & $(4.87)$ \\
\hline L2.Credit Rating & $-0.001^{* * *}$ & $(-4.22)$ \\
\hline Patent stock/L2.employees & $0.009^{* * *}$ & $(2.75)$ \\
\hline Share_ElectricalEng & $0.138^{* *}$ & $(2.48)$ \\
\hline Share_Instruments & -0.035 & $(-0.47)$ \\
\hline Share_Chemistry & 0.064 & $(0.87)$ \\
\hline Share_ProcessEng & 0.027 & $(0.47)$ \\
\hline Share_MechanicalEng & $-0.097^{*}$ & $(-1.68)$ \\
\hline Share_Consumption & $0.205^{* *}$ & $(2.33)$ \\
\hline Age & $-0.002^{* * *}$ & $(-3.63)$ \\
\hline Constant & $-1.772^{* * *}$ & $(-22.04)$ \\
\hline Observations & 37889 & \\
\hline
\end{tabular}

Significance: ${ }^{*} \mathrm{p}<0.1, * * \mathrm{p}<0.05, * * * \mathrm{p}<0.01$.

\begin{tabular}{|c|c|c|}
\hline & \multicolumn{2}{|c|}{$(1)$} \\
\hline & Coef. & t-value \\
\hline Ln(L2.employees) & $0.046^{* * *}$ & $(4.36)$ \\
\hline L2.Credit Rating & $-0.001^{* *}$ & $(-2.57)$ \\
\hline Patent stock/L2.employees & $0.008^{* *}$ & $(2.56)$ \\
\hline Share_ElectricalEng & 0.086 & $(1.49)$ \\
\hline Share_Instruments & -0.039 & $(-0.52)$ \\
\hline Share_Chemistry & -0.122 & $(-1.39)$ \\
\hline Share_ProcessEng & -0.015 & $(-0.27)$ \\
\hline Share_MechanicalEng & $-0.111^{*}$ & $(-1.89)$ \\
\hline Share_Consumption & $0.296^{* * *}$ & $(3.92)$ \\
\hline Age & 0.000 & $(1.16)$ \\
\hline Constant & $-1.895^{* * *}$ & $(-18.53)$ \\
\hline Observations & 21954 & \\
\hline
\end{tabular}

Significance: ${ }^{*} \mathrm{p}<0.1,{ }^{* *} \mathrm{p}<0.05,{ }^{* * *} \mathrm{p}<0.01$. 


\section{B Flowchart Proceedings}

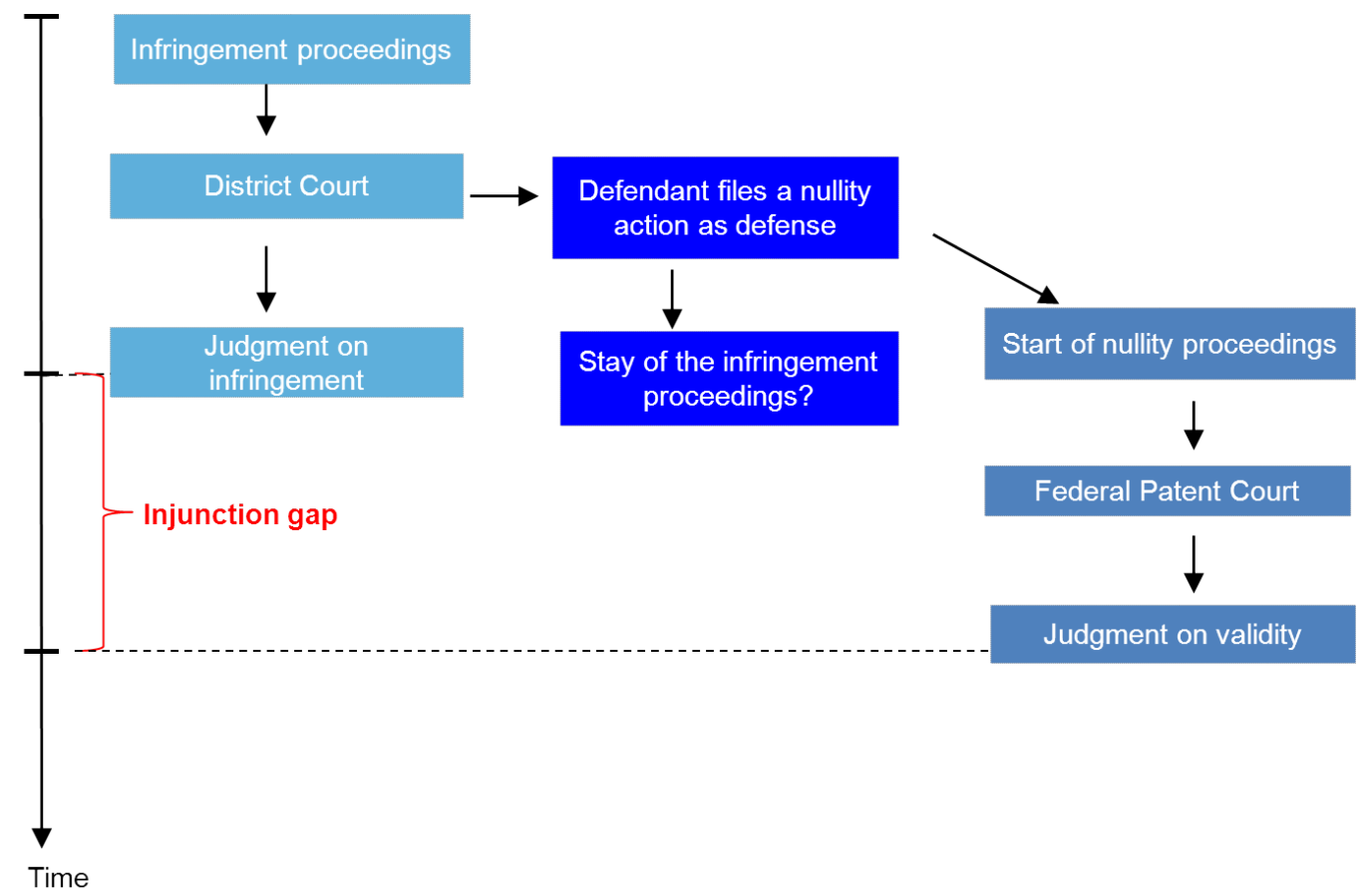




\section{An Example of a Litigation Case}

As an example of a litigation suit consider the case heard at the district court of Düsseldorf with case number 4b O 479/03. The case has been filed by BSH Bosch Siemens Hausgeräte GmbH on January 5th 2004 against the Italy-based firm Merloni Elettrodomestici regarding the Patent EP 92113435 titled "Refrigeration apparatus, especially refrigerator or freezer". Merloni Elettrodomestici sells refrigerators in Germany through its German subsidiary. BSH Bosch Siemens Hausgeräte accuses the defendant of the infringement of its patent on refrigerators and files for omission of infringement as well as damages. The defendant files for the dismissal of the case and parallely files a nullity suit at the Federal Patent Court in Munich on May 10th 2004. It requests a stay of the proceedings until a decision on validity has been rendered. Based on a low probability of success of the invalidity suit the Düsseldorf court refuses a stay of proceedings and judges on September 16th 2004 that infringement took place. The defendant is ordered to omit further infringement, to disclose exact numbers on produced refrigerators based on the disputed patent and to pay damages according to these numbers. The value at stake in this case was 500000 Euros resulting in a cost risk (court plus lawyer costs) of about 40000 Euros. The decision on validity is rendered only on the 3rd of May 2005, almost 9 months after the judgment on infringement: The court does not invalidate the patent ${ }^{11}$.

\section{Empirical Methodology}

Given the theoretical considerations and the advantages of using changes in credit rating data as a proxy for changes in firm value, the idea of the empirical approach is to analyze the impact of being involved in patent litigation on the credit rating of the firm. The impact of being involved in litigation on the rating of a firm can be calculated as follows:

$$
\alpha_{T T}=E\left(Y^{T} \mid L=1\right)-E\left(Y^{C} \mid L=1\right)
$$

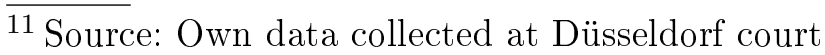


with $Y^{T}$ denoting the rating of a firm having been involved in litigation and $Y^{C}$ denoting the rating of the firm in case of not having been involved in litigation. Variable $L$ stands for the treatment status being 1 if the firm has received a treatment (litigation) and 0 otherwise. The average treatment effect on the treated $\alpha_{T T}$ thus results from comparing the rating of a firm involved in litigation to its (hypothetical) rating in case of not being involved in litigation. While the first term in equation 1 can easily be calculated by the sample mean of the rating of the treated firms the so-called counterfactual situation has to be estimated. While it is tempting to simply calculate the average rating of the firms not involved in litigation and subtract this from the average rating of the treated firms to obtain the average treatment effect on the treated, this can lead to a severe bias in the results. It is quite possible that the firms involved in litigation would have a different rating than the non-litigating firms even if they were not involved in litigation. This is because certain firms are more likely to be affected by patent litigation than others: different R\&D expenditures, differences in industry and size can result in an overall different condition of the firms. As factors affecting the litigation probability are at the same time affecting the future firm value, the treatment (being involved in litigation) is an endogenous variable in the estimation of firm value. The econometric literature on treatment effects suggests a number of methods that can be applied to control for this endogeneity problem. For a survey of the methods refer to Blundell and Costa-Dias (2009). Possible methods include instrumental variable estimations, selection models as well as matching estimators and difference-in-difference estimations. As instrumental variable and selection models require valid instruments for the treatment that are uncorrlated with the outcome variable and it is difficult to find such variables in the context of firm value and litigation, I will apply the conditional difference-in-difference estimator, a mixture of the matching method and the difference in difference estimator, in this paper.

The matching estimator is a non-parametric estimator to identify the treatment effect. It is aimed at finding a twin firm for each treated firm that matches with respect to a set of observable characteristics $\mathrm{X}$ that affects the selection into treatment, but does not receive the treatment. The difference in rating between the treatment group and the matched group of twin firms can then be attributed to the treatment. Rubin (1977) has introduced the conditional independence assumption that states that treatment and the rating outcome 
are independent for firms with the same exogenous characteristics X. Given that $\mathrm{X}$ contains all relevant variables that determine the treatment as well as the outcome, the counterfactual situation can be estimated by

$$
E\left(Y^{C} \mid L=1, X=x\right)=E\left(Y^{C} \mid L=0, X=x\right)
$$

The average treatment effect on the treatment can then be estimated as

$$
\alpha_{T T}^{M}=E\left(Y^{T} \mid L=1, X=x\right)-E\left(Y^{C} \mid L=0, X=x\right)
$$

given that the sample of non-treated firms offers a counterpart to each treated firm.

As the vector of observable characteristics $\mathrm{X}$ can contain numerous variables it becomes difficult to find non-treated firms that exactly match with respect to these characteristics ("curse of dimensionality"). In order to overcome this, Rosenbaum and Rubin (1983) have shown that the vector of observable characteristics can be reduced to a single index, the propensity score, which is the estimated probability of receiving a treatment. The matching can then be applied to this composite index. This methodology is called propensity score matching and I chose to conduct nearest neighbor matching, which keeps for each treated firm only the most similar control observation. It is possible to impose further restrictions on the control group, and I impose industry, a broad firm size category, a patent dummy and firm legal form dummies to match between the treated fims and their control firm.

While the advantage of the matching estimator is that it requires no functional form assumptions about the outcome equation, the disadvantage is that it controls only for observable differences between the treatment and the control group. Therefore I combine the matching estimator with a difference in difference estimator. The DiD estimator requires a panel database as it is based on estimating the counterfactual situation as the outcome of the treated firm in a period prior to the treatment. It is estimated as the difference between the outcome of the treated firm after the treatment and the outcome of the treated firm prior to its treatment. In order to control for general macroeconomic changes a second difference is calculated between the outcome of a non-treated control sample observed for the same time period. The DiD estimator is then calculated as the double difference:

$$
\alpha_{T T}^{D i D}=E\left(Y_{1}^{T}-Y_{0}^{T} \mid L=1\right)-E\left(Y_{1}^{C}-Y_{0}^{C} \mid L=0\right)
$$


The advantages of the DiD approach are straightforward: both common macroeconomic trends and constant individual-specific unobserved effects can be controlled for. The conditional DiD estimator now combines the advantages of the matching estimator with the advantages of the DiD estimator. By chosing the control group of the DiD based on a matching approach that ensures the treated and the control firms to match on the set of observables $\mathrm{X}$, common macroeconomic trends, constant individual-specific unobserved effects as well as observable differences between the groups can be controlled for (Heckman et al. 1998). It is estimated by

$$
\alpha_{T T}^{C D i D}=E\left(Y_{1}^{T}-Y_{0}^{T} \mid L=1, X=x\right)-E\left(Y_{1}^{C}-Y_{0}^{C} \mid L=0, X=x\right) .(\mathrm{D} .5)
$$




\section{References}

Bessen, J. and Meurer, M. (2008a). Patent Failure. How Judges, Bureaucrats, and Lawyers Put Innovators at Risk. Princeton University Press.

Bessen, J. and Meurer, M. (2008b). The Private Costs of Patent Litigation. Boston University School of Law Working Paper Series. Law and Economics Working Paper No. 07-08.

Bessen, J. and Meurer, M. (2005). The Patent Litigation Explosion. Boston University School of Law Working Paper Series. Law and Economics Working Paper No. 05-18.

Bhagat, S., Brickley, J. and Coles, J. (1994). The Cost of Inefficient Bargaining and Financial Distress. Evidence from Corporate Lawsuits. Journal of Financial Economics 35(22), p. 1-247.

Blundell, R. and Costa Dias, M. (2009). Alternative Approaches to Evaluation in Empirical Microeconomics. The Journal of Human Resources 44(3), p. 565640 .

Busche, J., Fabry, B. and Trimborn, M. (2010). Patent Infringement Worldwide. Claim Interpretation-Infringement-Damages. Heymanns Intellectual Property. Carl Heymanns Verlag, Cologne.

Collins, K. E. (2009). Patent Failure: A Tragedy of Property. mimeo.

Czarnitzki, D. and Kraft, K. (2004). Innovation Indicators and Corporate Credit Ratings: Evidence from German Firms. Economics Letters 82, p. 377384 .

Czarnitzki, D. and Kraft, K. (2007). Are Credit Ratings Valuable Information? Applied Financial Economics 17(13), p. 1061-1070.

European Patent Office (2010). Patent Litigation in Europe. An Overview of the National Patent Litigation Systems in Europe. 2nd edition November 2010 .

Farrell, J. and Shapiro, C. (2008). How Strong Are Weak Patents? The Amer- 
ican Economic Review 98(4), p. 41347-69.

Greenhalgh, C. and Rogers, M. (2007). The Value of Intellectual Property Rights to Firms and Society. Oxford Review of Economic Policy 23(4), p. 541-567.

Hall, B.H. (2000). Innovation and Market Value. In: Barrell, R., Mason, G., O'Mahony, M. (Eds.), Productivity, Innovation and Economic Performance. Cambridge University Press, Cambridge.

Hall, B.H., A.B. Jaffe and Trajtenberg, M. (2005). Market Value and Patent Citations, Rand Journal of Economics 36(1), p. 16-38.

Harhoff, D. (2009). Economic Cost-Benefit Analysis of a Unified and Integrated European Patent Litigation System. European Comission. Final Report Tender No. MARKT/2008/06/D.

Heckman, J.J., Ichimura, H. and Todd, P. (1998). Matching as an Econometric Evaluation Estimator. Review of Economic Studies 65(2), p. 261-294.

Jaffe, A. B. (1986). Technological Opportunity and Spillovers of R\&D: Evidence from Firms' Patents, Profits, and Market Value. American Economic Review, 76(5), p. 984-1001.

Lemley, M. A. and Shapiro, C. (2005). Probabilistic Patents. Journal of Economic Perspectives 19(2), p. 75-98.

Lerner, J. (1995). Patenting in the Shadow of Competitors. Journal of Law and Economics 38(2), p. 463-495.

Lechner, M. (2001). Identification and Estimation of Causal Effects of Multiple Treatments under the Conditional Independence Assumption. In: M. Lechner and F. Pfeiffer (eds.), Econometric Evaluation of Labour Market Policies, Physica, Heidelberg, 43-58.

Marco, A. (2005). The Value of Certainty in Intellectual Property Rights. Stock Market Reactions to Patent Litigation. Vassar College Economics Working Paper 82.

Meissner Bolte (2012). IP-Litigation in Germany in a nutshell: Why Litigate 
IP in Germany? Meissner Bolte, German and European Patent, Trademark and Design Attorneys Attorneys at Law. Retrieved December 16th 2012 from: http://www.mbp.de/fileadmin/user_upload/pdf/broschueren/IP-Litigation_ in_Germany-Webversion.pdf.

Nordhaus, W.D. (1962). Invention, Growth, and Welfare. A Theoretical Treatment of Technological Change. MIT Press, Cambridge, MA.

Pitz, J. (2010). Patentverletzungsverfahren. Grundlagen-Praxis-Strategie. Verlag C.H. Beck oHG, München.

Raghu, T.S., Woo, W. , Mohan, S.B. and Raghav Rao,R. (2008). Market Reaction to Patent Infringement Litigations in the Information Technology Industry. Information Systems Frontiers 10, p. 61-75.

Rosenbaum, P. R. and Rubin, D. B. (1983). The Central Role of the Propensity Score in Observational Studies for Causal Effects. Biometrica 70(1), p. 41-55.

Rubin, D. B. (1977). Assignment to Treatment Group on the Basis of a Covariate. Journal of Educational and Behavioral Statistics 2(1), p. 1-26.

Scotchmer, S. (2004) Innovation and Incentives, MIT Press, 2004.

Shapiro, C. (2010). Injunctions, Hold-Up, and Patent Royalties. American Law and Economics Review 12(2), p. 280-318.

Stauder, D. (1989). Patent-und Gebrauchsmusterverletzungsverfahren in der Bundesrepublik Deutschland, GroSSbritannien, Frankreich und Italien. MaxPlanck-Institut für für ausländisches und internationales Patent-, Urheberund Wettbewerbsrecht. Schriftenreihe zum gewerblichen Rechtschutz Band 79. Carl Heymanns Verlag KG, Köln, Berlin, Bonn, München.

Traitenberg, M. and Jaffe, A. (2002). Patents, Citations and Innovations: A Window on the Knowledge Economy. MIT Press, 2002.

Wang, Y., Shih, K. and Chuang, Y. (2010). Market Behavior of Patent Infringement Litigations. African Journal of Business Management 4(4), p. 390395.

Ziedonis, R.H. (2003). Patent Litigation in the Semiconductor Industry. In: 
Patents in the Knowledge-Based Economy, ed. W. Cohen and S. Merrill (National Academy Press: Washington DC), p. 180-215. 